\title{
Pandemic, Human Precarity and Post-Pandemic Metaverses
}

Tracy Harwood

De Montfort University

Follow this and additional works at: https://digitalcommons.uri.edu/mgdr

Part of the Anthropology Commons, Economics Commons, Marketing Commons, Other Business Commons, Philosophy Commons, Science and Technology Studies Commons, and the Sociology Commons

\section{Recommended Citation}

Harwood, Tracy (2020) "Pandemic, Human Precarity and Post-Pandemic Metaverses," Markets, Globalization \& Development Review: Vol. 5: No. 4, Article 3.

DOI: 10.23860/MGDR-2020-05-04-03

Available at: https://digitalcommons.uri.edu/mgdr/vol5/iss4/3

This Dialogue is brought to you for free and open access by DigitalCommons@URI. It has been accepted for inclusion in Markets, Globalization \& Development Review by an authorized editor of DigitalCommons@URI. For more information, please contact digitalcommons-group@uri.edu. 


\section{Markets, Globalization \& Development Review}
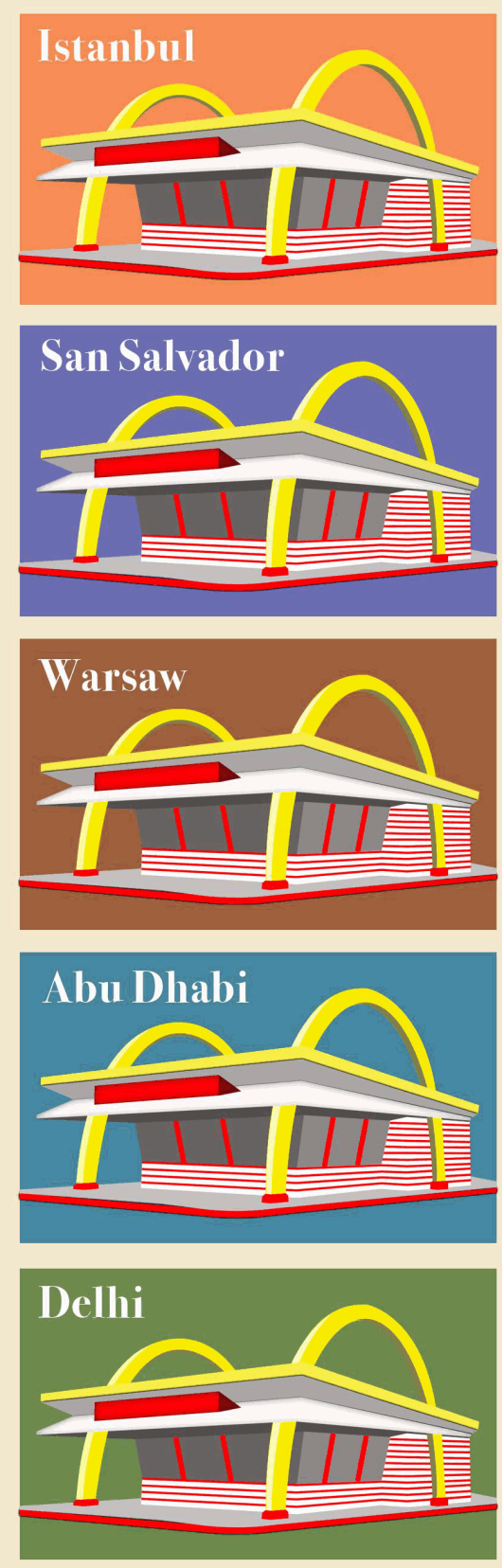
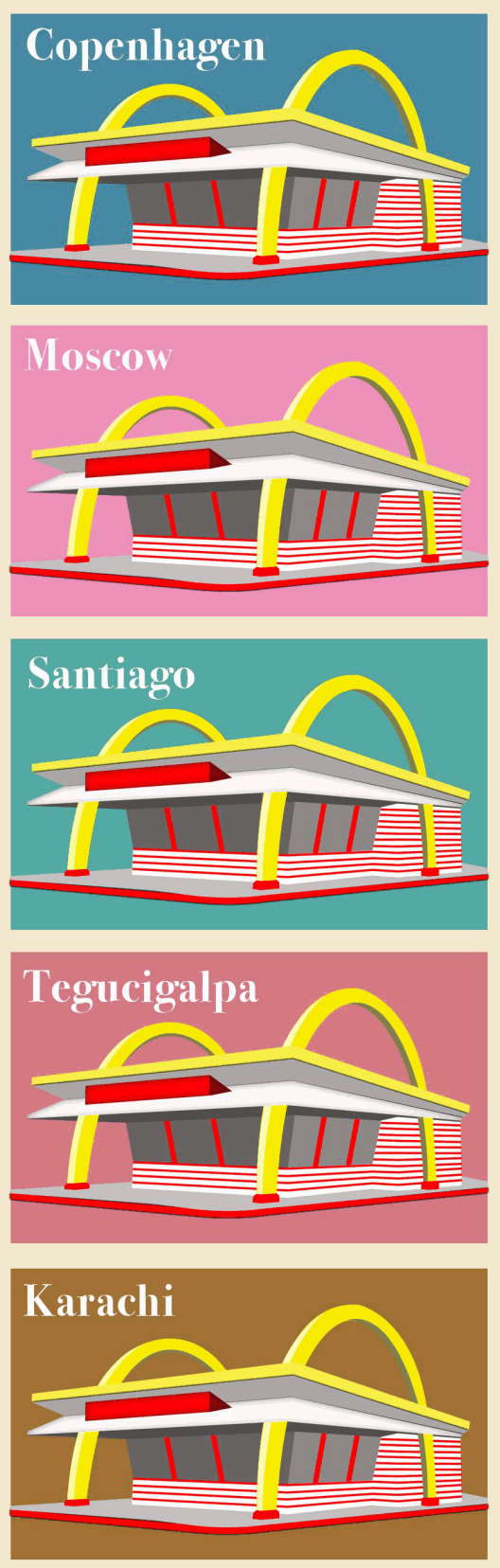
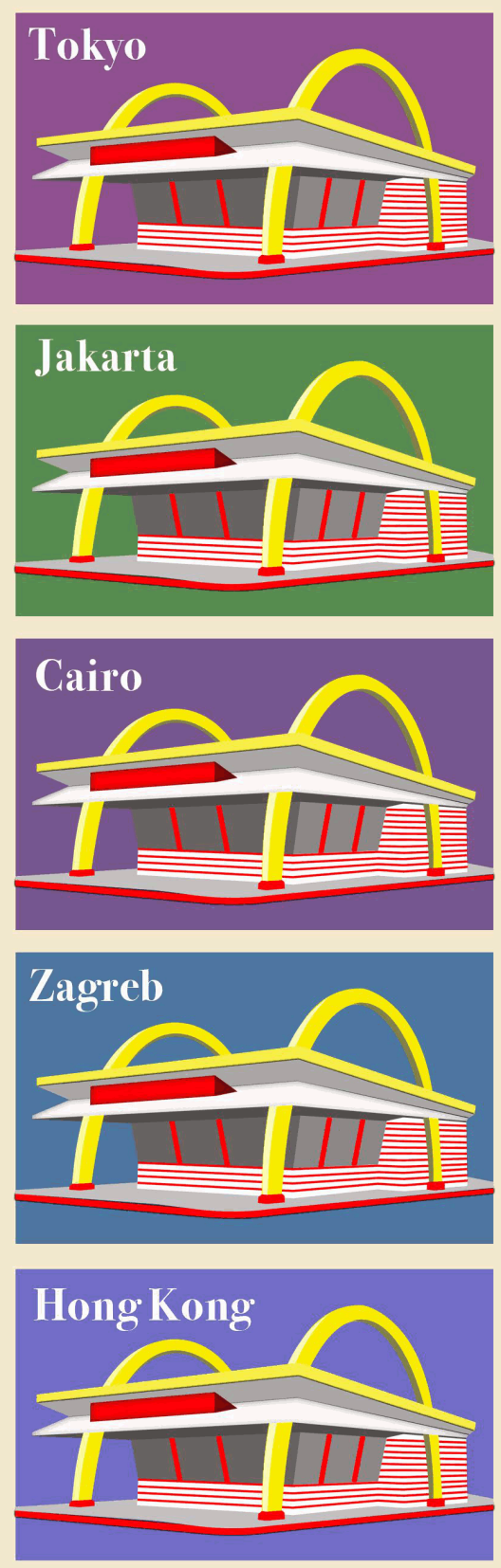

This dialogue is available in Markets, Globalization \& Development Review: https://digitalcommons.uri.edu/mgdr/ vol5/iss $4 / 3$ 


\section{Pandemic, Human Precarity and Post- Pandemic Metaverses}

\section{Introduction}

The COVID-19 global pandemic has shone a light on the precarity of humanity like nothing else in our recent history - war takes the lives of the younger people and displaces many, but this virus is noted as an existential threat to the older as well as the socially and medically diminished members of society, disrupting global social and health systems in its wake. Whilst the United Nation's Sustainable Development Goals (SDG) were already noted to be under-achieving, the objectives for 2030 now seem unattainable. This jeopardizes basic human needs for survival such as food security and health, not least, because the underpinning assumptions on which the SDGs are based have been irrevocably changed by the pandemic (Naidoo and Fisher 2020). Indeed, Naidoo and Fisher (2020) argue that if nations were performing in line with the SDG targets concerned with poverty elimination, universal health access, and agricultural productivity, the pandemic would not have been the devasting wrecking-ball as it has been. What is clear from the environmental research reported to date is that human proliferation and behavior (over-population, pollution, deforestation, degradation of land) has put pressure on the natural balance in our immediate environment and on the planetary ecosystems as a whole. This has resulted in loss of biodiversity and climate change.

Some argue that the current pandemic is a 'moment of truth' in our evolution - a time for critical self-reflection and an opportunity for resolution where less consumption equals more focus on 'things that matter' such as local ecosystems. As Booker prize-winning author Arundhati Roy states "Historically, pandemics have forced humans to break with the past and imagine their world anew. This one is no different. It is a portal, a gateway between one world and the next..." (Roy 2020; see also Cambefort 2020 and Hong 2020 in MGDR). It is unsurprising that data released by NASA (National Aeronautics and Space Administration) and ESA (European Space Agency) intimate the reduction of pollution as a consequence of the (enforced) lack of movement of people during the global lockdowns; in the past year, this reduction has been as much as 30\% in some areas such as Wuhan (China), Italy and Spain (e.g., Rupani et al. 2020). Yet, the pandemic has also exacerbated our relationship with technologies, especially information and communications technologies, in the race to 'get online' and 'stay in touch' as well as entertain and inform ourselves 
through endless variety of multidimensional virtual platforms. We have become cyborgs (Haraway 1985; Huang \& Rust 2018) - of necessity via a transhumanist melding of our bodies and minds with technologies, without which our now restricted human world would be significantly diminished.

Attendant to this, we are now witnessing a global shortage of semiconductors as a consequence of disrupted supplies and increased demand. Ever this was the trajectory: we have known for some time that our technology consumption patterns would be unsustainable. Current chip-based technologies are wholly reliant on the use of a finite supply of Earth's resources such as minerals, fossil fuels and Rare Earth metals, 95\% of which are accounted for by Chinese producers (Vekasi 2019). Furthermore, the numerous attempts by an increasing number of government-backed public and private organizations to explore beyond the confines of our planet - the Moon, Mars, Jupiter, Saturn, Venus and various asteroids and comets - with the aim of examining potential opportunities for furthering human endeavor has gained new impetus, albeit this has been planned for years. Indeed, the pandemic seems to have accelerated not just transhuman and posthuman trends, but also post-global and extra-global trends (see the MGDR review of 'Elysium'; Ulusoy 2020).

We have reached a nexus which places new emphasis on our understanding of ourselves and our relationship with others - other nations, other species, other worlds. A critical question is: Does this mean that our transition into the posthuman is complete? It is therefore with some interest that I approached the review of Francesca Ferrando's book (2019) titled Philosophical Posthumanism.

The next several pages - the major part of this essay - are devoted to my review of this book, after which I return to my own commentary on what this book and ongoing research insights reflect on the emergent, fledgling post-pandemic settings.

\section{Review of Philosophical Posthumanism}

Philosophical Posthumanism provides a thought-provoking perspective on the different theories of how we are posthuman. Its central position is that humans are entities indelibly interrelated with others, human and non-human, organic and inorganic, rather than agents acting through transcendental consciousness. In fact, this monograph is a translation of a 2016 Italian version of Ferrando's doctoral thesis, which itself was awarded the 'Sainati' Philosophical Prize by the president of Italy in 2014. Ferrando, it is worth noting, is the first person to have presented a TED talk on the posthuman in December 2012 and is the founding director of the New York Posthuman Research Group. 


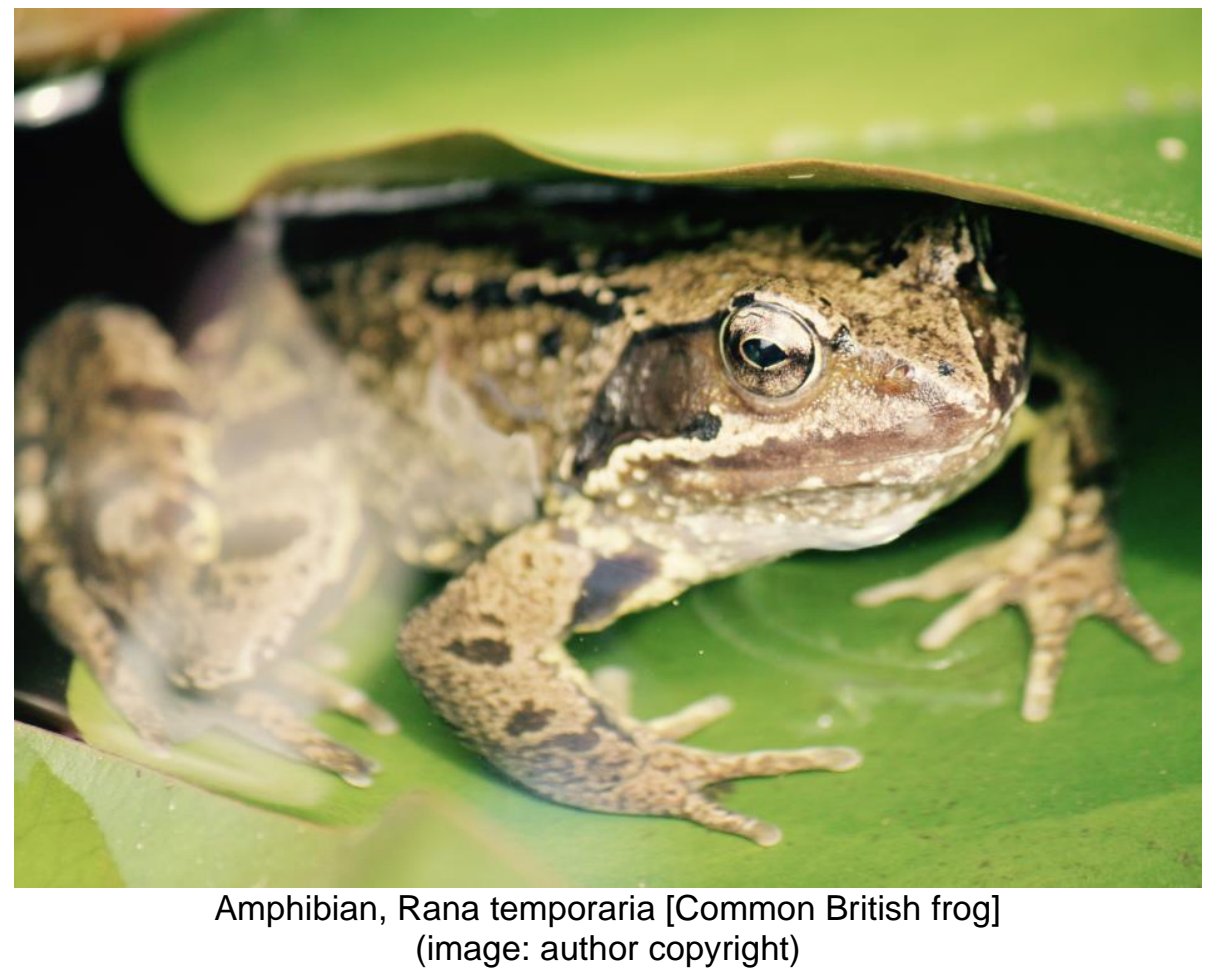

Her thesis presents two interrelated discourses, organized into three sections. First, Ferrando presents a critical review of the different perspectives of the posthuman including terms she argues it now encompasses such as posthumanism, transhumanism, new materialism, anti-humanism, object-oriented ontology, posthumanities and metahumanities. Second, her work extends the field by presenting new thoughts on ontology, epistemology and ethics in posthumanism. Third, she acknowledges how human others have evolved and how, in turn, these influence our understandings of what it means to be posthuman, by answering the question: of which post are we human?

What is interesting is that her take is not a techno-reductionist perspective but one that explores existential potentials through notions of a self/other continuum, drawing initially on Foucault and Heidegger as a means to explore technology and its multifarious relationships with humans and others. Similarly, her perspective of the human integrates the many dis-humanizing and anti-humanizing perspectives that have arisen in recent history, encompassing for example exclusionary discourse and practices such as sexism, racism, classism, ageism, homophobia, ableism, etc. By developing her thesis on posthuman dualities arising as a consequence of hybrid practices with animals, machines, and non-human others, she raises issues related to bios (pertaining to human experience) as well as zoë (pertaining to biological life), touching on historical and biological concepts informed by Nietzsche (embodied characterization) and Maturana \& Varela 
(autopoiesis). She also examines new materialism as a lens, considering the nature in which the human is networked and encompassed within a network, drawing on Latour and Deleuze \& Guattari to explore a multiverse perspective on speculative perceptions of self.

These are all deeply conceptual themes and, as a reader, one is left with a feeling of having been presented with a delectable salmagundi or bag of Liquorice Allsorts ${ }^{\mathrm{TM}}$ from which to taste a persuasive preference.

\section{Perspectives}

Her review of philosophical perspectives helpfully begins by exploring the key differences between the posthuman and transhuman, drawing on a Western philosophical understanding of technological mediation versus biological enhancement. In discussing post, she argues that theory is embodied in humanism, enacted by humans and accessed through an epistemic perspective of feminist self, being both plural and relational. Posthumanism is defined as the mediated self and speculation about possible future human developments as a consequence of reflecting on what may have been omitted from human. It is the need to understand what has been omitted that situates her argument to develop a posthumanist agenda.

Tracing developments in humanism through acceptance of 'anthropocentrism', Ferrando discusses notions of other in the human condition. This essentially links to Braidotti's (2002) notion of proliferating differences, placing those others defined by difference at the margins of society (witches, women, people of colour, disabled, queer, etc.). It was Hassan (1977) who first discussed posthumanism in his work on postmodernism, as he explored the possibilities for post in an inclusive context. Coupling this with development of cybernetic organisms (e.g., Haraway 1989) in the context of cultural posthumanism, Ferrando argues that humans become hybrid animate/mechanized entities, ultimately studied under a breadth of research themes (transhumanism, antihumanism, metahumanism, posthumanities, metahumanities, non-human turn, etc.); the distinctions between which are no longer clear. Ultimately, the term posthuman captures it all.

Indeed, in attempting to address the question 'are we already posthuman?' it is clear that the answer depends upon the perspective one takes. From a transhuman perspective, the answer lays somewhere between 'probably just about' to 'not quite yet' (at least artificial organs such as pacemakers do work); but from a posthuman perspective, the answer is definitely yes, and we have been since our prehistoric ancestors first selected a hammerstone over $1.7 \mathrm{M}$ years ago. Of course, more philosophically, Ferrando refers to our 
understanding and deconstruction of other through multiple threads of discourse in literature, rather than our state of being in the world.

The discussion of transhuman highlights the very real challenges faced in developing an inclusive position: we are not born transhuman (until such time as molecular level interventions are common in the population á la Pearce's 'paradise engineering'), meaning other becomes a significant point of difference as a consequence of socio-cultural and economic conditions. Thus, glocal in this context is not a choice: early proponents position it as a form of Enlightenment emanating from rationality, uncritical of progress through scientific and technological advancement (More 2003). In this regard, it is Foucault (1975) that highlighted how philosophy and social discourse are relationally linked to politics and power, where technology may be both simultaneously progressive and regressive, depending on one's point of interaction. For example, the atomic bomb may have ended hostilities between the US and Japan, but its consequences were dire for the Japanese people and profound for the rest of the World. Similarly, the treatise on rationality has led to dominance of man, resulting in inequality, discrimination, enslavement and violence against the other. Furthermore, technological enhancement commonly associated with the transhuman movement advocates morphological freedom through bioengineering and selfmodification, often presented as a dualism or separation of mind from body ('I think, therefore I am').

Extending this mind/body separation, Kurzweil's (2005) Singularity is seen as an ultimate transcendence of technology over biology, where the mind overcomes the mortal coil of the flesh body. Transhumans may thereby somehow project their mind into the body of an-other, which may be human, machine or object, and live in perpetuity. Through another perspective or point in time related to a different socio-cultural evolutionary pattern, however, such separation may easily be constituted as uncritical, undesirable and self-harmful.

Conversely, Ferrando examines the trajectory of the posthuman perspective of technology, highlighting it as a non-separate trait drawing on Heidegger's praxis. Heidegger's view of technology was that it is not simply a means to an end but a manner of revealing or 'enframing' some aspect of human condition; hence, it is not the technology that may cause harm but the human who wields it. She also draws on Nietzsche's metamorphoses of the spirit, in which the human is portrayed as a bridge rather than a purpose, examining the role of God as a metaphor for authority or mediation in the posthuman turn. Touching on a number of other philosophical movements (New Realism, Speculative Realism and Object-Oriented Ontology), she concludes that whilst posthuman is an umbrella term, it encompasses challenge to our understanding of the boundaries of what is considered 
to be human. Post being the operative term: she positions philosophical posthumanism as comprising post-humanism, postanthropocentrism and post-dualism. Post-humanism refers to understanding of the plurality of human-kind experiences; postanthropocentrism is the recognition that humans have been hierarchically privileged over non-humans through the ages; and, postdualism is the way in which self is diametrically symbolized against other (us/them, friend/enemy, etc.).

Treading a delicate line, Ferrando's text provides a reassessment of philosophical posthumanism, aligning her work closely to Braidotti's key work, The Posthuman (2013). It is the hybridization of man with other (animal, machine, object) that necessitates an altered view of the human. This does not contradict previous work on the posthuman but rather extends our understanding. Braidotti's work presents a map of main tenets including post- self, species, death and theory but, Ferrando argues, does not deal adequately with the separation between life and death. She states that it is particularly important to understand where the human is decentred to in order to make sense of what may be new and different. For example, in Western study, identity (humanist) is often centred in discourse which has resulted in 'radical' deconstruction of others at the periphery (women, blacks, queer, etc.). The dualities of hierarchical status that other implies, however, will always result in discrimination, so in Ferrando's view, it is essential that post-dualism (or non-dualism) is embraced as a decentring tenet. This brings posthumanism closer to Eastern philosophy, and the 'profound harmony' of The Tao (e.g., Capra 2010).

\section{Post-humanism}

The second part of Ferrando's book deals with the etymological, semantic, linguistic and scientific structures and construction of the term post[-]humanism, particularly in reflecting what human means. From an etymological standpoint, breaking the term into its constituent parts, post is a crowded space: post has been employed almost as a fashion statement, indicating what follows, beyond or after - postcolonialism, post-truth, post-apocalyptic, and so on. Its role is to communicate the before, in essence emphasizing a trajectory of development and legitimizing the now. The hyphen too is a victim of fad, disappearing as terms become more commonplace, hence posthumanism becomes posthumanism. Thus, her focal discussion is on the humanism part of the term, and its discontents, wherein she reflects on the nature of other and how this is represented through different lenses. 
Ferrando argues that other is a necessary yet relational (semantic) configuration which enables us to make sense of interdependencies and affinities in the use of the term human. She does this by drawing particularly on gender theory, using De Beauvoir's (1949) observance of how woman is defined in sexual relation to man ('one is not born, but rather becomes a woman' p.301) and Irigaray's (1974) view of how woman is simply absent rather than other. In both cases, the concept of man (and other) becomes ritualized through a process, leading her to explore the question of how humanizing takes place through embodiment as a process.

Her thesis is that posthumanism is praxis and thereby highlights the importance of using non-discriminatory language to explore process. This is extremely challenging to achieve particularly given McLuhan's (1964) 'medium is message' truism reflecting the duality of the what and the how being embedded within cultural artefacts themselves. Language is tied to culture but when extending this to include other, say animal, machine or object, the way and how becomes increasingly complex, multi-layered and multi-dimensional. Consider, for example, the mathematical code/language of polygons used to create virtualized humans, the algorithm/language used to generate routines and behaviours that are embodied in neural networks, and the storytelling/language embodied within creative practice such as dance and music.

Understanding the process of humanizing is therefore not a trivial task. The way she goes about this is by exploring what is excluded from the notion of the relational human through an analysis of dehumanization: how slaves, subhumans, nonhumans, monsters, automata and many other categories of humans at the periphery have been thought of beyond normalized ideas of man. She then turns this around by asking what those categories of other humans experience in the humanizing process. She argues that by doing this, all possible alternative categories of human are targets for investigation through the lens of the posthuman.

Another interesting and contemporary reflection Ferrando makes in this domain is how a posthuman lens provides a relational overview, not just of the human through biological and geographical (physical) intra-connections between humans but also of how humans relate to the planet. She does this by drawing on Teilhard de Chardin's paper, 'From the Pre-Human to the Ultra-Human: The Phases of a Living Planet' (1964). This is particularly relevant today in our postCOVID19 anthropocentric world where socio-economic recovery is interrelated with our ability to create a more sustainable environment. In many ways this can only really be achieved through a global overview of the key issues applied to a local context. 
Archaeologically unpacking the term human, Ferrando reflects on its origins from Greek and Roman times - Greek for human is anthropos, giving rise to our use of anthropology, anthropocentrism, etc., but this also originally reflected culture and education. It was for example Aristotle who defined human as a political being, yet polis meant civilization and hierarchy within city life (Athens) at the time, where other was excluded and woman, slave, and non-Greeks were referred to as barbarian. Thus, the term human relates to culture, reason and civilization. In this context, Ferrando traces how the word is adopted by early playwrights but, in so doing, argues that it was mainly developed by free male intellectuals rather than including peripheral categories of human. This again is therefore exclusionary and positions the posthuman as a necessary development for progression, even though the term humanity is an attempt to reflect inclusivity in its broadest sense.

From a scientific standpoint, Ferrando positions her discussion in the context of speciesism and the system of biological classification developed by Linnaeus (1758), where Homo sapiens was determined as a category of mammal (familia primate) defined by differentiating characteristics (genus, familia, ordo, etc.). Linnaeus' Homo sapiens (referring to genus and species) also included a taxonomy of five groupings based on race (continent, skin colour and other defining features) as well as a monstrous taxon which dealt with outliers such as those with congenital disformities (dwarf, giant, other birth defects). This classification was based on a Eurocentric perspective which still informs our construction of human and within species differentiation today, not least because the methodology was configured by Western human endeavour. Following this line and situating the primacy of (Western) human, for example, Agamben (2002) argued that to be human, one must recognize oneself as human and, of course, this becomes problematic when considering different races classify themselves in different ways, such as according to cultural practices (eg., indigenous tribes). Ferrando argues that posthuman therefore destabilises Linnaeus' classification, which is actually based on his strict Lutheran upbringing as much as it is scientific praxis, wherein woman nurtures (ordo of mammal derives from mammalia, meaning breast, a term coined by Linnaeus) and man engages in intellectual activities.

In conclusion, the term human in posthumanism is not neutral but imbued with socio-political, economic and symbolic meaning that predetermines potential for exclusivity rather than inclusivity of other. Ferrando highlights the importance of recognizing these deficiencies in our use of the language and, through it, sets the scene for developing the field of philosophical posthumanism. 


\section{Post Posthuman}

The final section of Ferrando's text develops her thesis on philosophical posthumanism simply by asking what follows the anthropocene. As well as situating her discussion within a geologicalchronological discourse drawing on Latour she also shapes this by drawing on Haraway's 'response-ability' (2017) for shaping the Earth. Her approach is by way of asking how the anthropocene has been contested, highlighting Parikka's (2014) anthrobscene (the obscenities of media ecologies), Moore's (2016) capitalocene (profit-based) and Haraway's (2016) chthulucene (where human and non-human are inextricably linked in tentacular practices). She argues it is high time for a paradigm shift and does not much mind whether that is termed post-humanism, post-anthropocentrism or post-dualism.

This is probably because Ferrando's argument centres on Gaia theory as a 'cosmic embodiment that cannot be silenced'. Gaia theory connotes the interdependencies between all components of Earth, such as biological and geological structures. Drawing on Stengers (2015) and Latour (2017), she makes a compelling argument that there is no future in which man will thrive by ignoring Gaia, albeit this theory subverts the trajectory of human Enlightenment. As she notes, however, man cannot simply be removed and even though the posthuman is a clear means by which to question the intraconnections, ultimately even dead man in its bare form impacts Earth (as compost). 


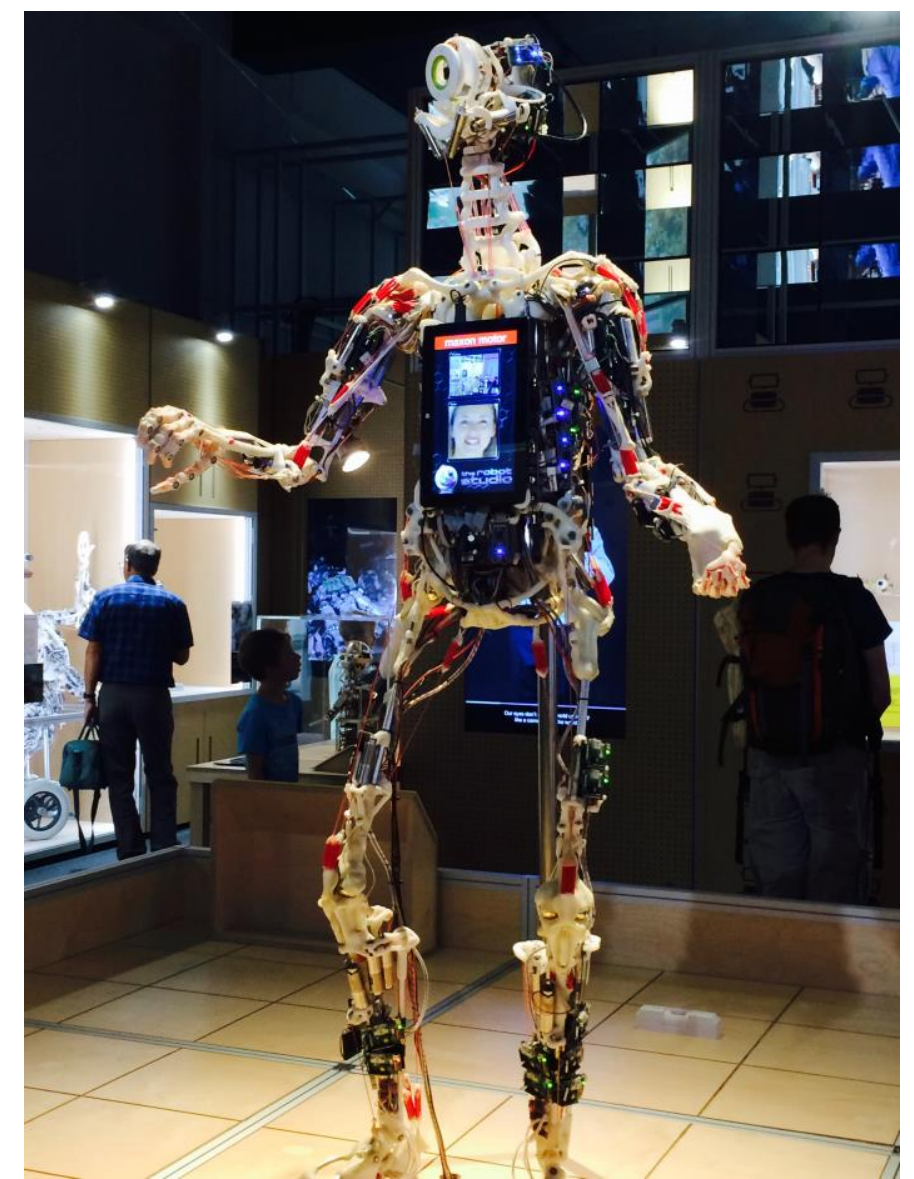

Rob's Open Source Android, ROSA, built by Knight (2016), photographed on display at the Science Museum's Robots: 500-Year Quest to Make Machines Human exhibition, 2017

(image: author copyright)

It is at this juncture that she creates an interesting link to the transhuman perspective, where life and death co-exist in a continuously evolving cycle of re-generation at both micro and macro levels (e.g., cellular and body). If human life can be extended ad infinitum (Kurzweil), how relevant is this dichotomy within a posthuman turn? This leads her to question what is posthuman life, again engaging the reader with etymological and scientific perspectives. Using the origins of Greek terms, she differentiates between bios (pertaining to man) and zoë (pertaining to all life), both of which are also sociopolitically derived. She argues life is particularly difficult to define (e.g., virus is neither alive nor dead) and instead asks the question of the relativity of life to death as meaningful for understanding posthumanism. Through this, animism is a term that is forwarded. As Ferrando states, however, whilst grounded in Eastern philosophy (Shintoism), the term animism is useful as a transcultural (rather than Western hegemonic) perspective yet the dichotomy 
(animate/inanimate) remains and is not particularly useful in understanding technologically advanced posthuman life. Mori's (1970) uncanny valley effect, for example, illustrates how inanimate robots may be perceived as animate and/or spiritual beings (Mori 1974) in many cultural contexts. By way of example, the robot (Knight 2016) image above illustrates an anthropomorphic representation, but the particular robot identified was also programmed to move like a human which animates it.

The robot/human discourse also results in otherness and consequential discrimination (e.g., anti-autonomous agents movement) and so Ferrando argues that philosophical posthumanism must consider the symbioses between human and other. This becomes particularly relevant in a technology context, where liveness of say a robot is a current hot topic in a number of fields including arts, humanities as well as science and technology. Ferrando approaches the question by asking how life can be artificial, drawing on Langton's (1986) notion of cellular automata as a means to interrogate why it is necessary to consider a machine as organic for it to be alive. Life according to Langton is an abstraction of logical form emanating from molecular level code (e.g., DNA strings), his argument being that if it is simply code that determines life, then artificially codified life is possible. Ferrando then extends her discussion by considering the nature of virtual disembodiment as an illustration of logical form, taking Warwick's (2012) and others' position that it is preferable to have biological embodiment in order that a cybernetic organism may fully understand its physical environment and be persistently aware.

Having turned this around to advance her thesis, therefore, Ferrando argues that a view of biological $\mathrm{Al}$ is a necessary perspective (again overcoming the dualism of organic/inorganic) to position Channell's (1991) worldview of the future roles of genetics, quantum physics and super-intelligence. She is quick to address the issue that such a perspective positions philosophical posthumanism as technocentric, arguing that by addressing the animate/inanimate dualism, the approach neither excludes nor places hierarchies on other. Instead, the new discourse decentres the debate around primacy of one over another and allows for a broader discourse encompassing diversity and sustainability.

The ability to do this is predicated on her argument around a common ancestor - a primordial single cell from which all life on Earth is believed to have begun, drawing on Lamarck's (1809) transformism where characteristics are inherited between generations, Darwin's (1852) On the origin of species by means of natural selection and Woese's (1998) argument that a universal origin is a process that connotes gene transfer across a community of cells which combine and recombine into organisms through evolution. Evolution is 
evidenced in the general ability to interbreed between species (of course there are exceptions) and as such there are likely to be no fixed boundaries as implied by Linnaeus' classification system. Evolution is therefore a natural-cultural continuous process notwithstanding that eugenics (selection for desirable traits) and epigenetics (the influence of nurture) have resulted in undesirable aspects such as primacy and exploitation (e.g., racism, ableism and genocide). Ferrando uses Shiva's (1995) counter-argument against genetic modification as an example of perverse yet inevitable post-anthropocentrism which raises political, economic, social and ethical issues. Artificial selection is a posthumanities worldview because it opens the discourse to both posthumanist and transhumanist perspectives.

Focussing on a bioethical perspective of technological enhancement, philosophical posthumanism raises many questions not so much related to the whether it is possible and what comes after, but more whether it should be allowed in the first instance. This is not just about the human condition but about the role of human in other. Ferrando's discussion centres on the precautionary versus proactionary principle, posited by More (2004). The precautionary standpoint describes a legal/illegal dichotomy for the transhuman based on the potential for creating disparity and discrimination. The proactionary standpoint is about dealing with the consequences as they arise but by fundamentally recognizing the freedom [of people] to influence their own evolution. Technological enhancement, by its very nature, brings into question the roles of others - who has control over the technology, what happens to the data it generates, etc. giving rise therefore to further socio-political considerations. For example, Ferrando discusses intervention at the molecular level to enhance human life prospect (removing the likelihood of contracting life limiting conditions such as cancers and diseases from our genetic code) but perhaps, taking her Gaia argument forward, that intervention might view the prospect of reproductive rates of one decentred entity, without hierarchical primacy, to balance and sustain planetary conditions thereby reducing human lifespan or tolerance to natural conditions. Her posthuman perspective of technological advancement is therefore incomplete and avoids some of the thorny discourses that exist today around global sustainability and the posthuman, albeit she does revisit this later in the text.

Drawing on Maturana \& Varela (1972/1980) to further explore the notion of life and its role in the posthuman, Ferrando turns to the issue of self-sustaining life (autopoiesis) as a cognitive process. She reflects on Haraway's (2017) view that nothing is really capable of selforganizing, preferring instead to use the term sympoiesis to describe a relational process. Cognition is a scientific construction of knowledge, whereas epistemology is a philosophical approach (the actual process 
versus the how it happens). To illustrate her point, she uses an example of the frog: observed by Maturana and others, the eye of the creature only recognizes food when it behaves like food, a moving insect say, whereas if food around it did not move it would starve. This indicates a species-specific organization of language. Her point is made in the context of understanding ethics of human experimentation on animal other and its role as a methodology for the posthuman, where such experimentation is largely justified and undertaken as a methodology of human advancement (over other).

She extends the point to assess life of the robot, drawing on Turing's (1950) groundbreaking work to argue that if a machine acts intelligently then perhaps it is and the posthuman is thereby about perspectivism. Thus, the human-centric fear of a potential existential threat from artificial intelligence would be replaced with a plurality of embodiment. To further her discussion, she aligns Nietzsche's view of perspectivism on which posthumanism draws heavily. Nietzsche (1901) stated that there are no absolute truths, only interpretations. It is the interplay of different interpretations and situated standpoints that provides the basis of a plurality of understanding about the posthuman. Albeit his examination of this was from an acknowledged human standpoint, he was aware of, and did not rule out, other in his discourse. Ferrando argues this is consistent with Braidotti's notion of embodiment (of mind), which rather than being separated as mind/body, recognizes the 'embrainment' of body. This is in tune with the discourse that the body does not have to be biological (e.g., Barad, 2007) which allows Ferrando to discuss alternative embodiments such as avatars and shamanism.

Ferrando also engages in a discussion of matter and its relationship to other, enabling her to critique Object Oriented Ontology (OOO) (e.g., Harman 2015). She states that although there are common elements, the central thesis of 000 gives primacy to other over human, which diverges with a dualistic standpoint of philosophical posthumanism. The argument centres on the relevancy of matter, through which Ferrando interestingly explores string theory. From physics, string theory (different to particle physics) is the view that all subatomic matter is a vibrating, uni-dimensional string of energy, which gives rise to particles based on the characteristics of the vibration, which in turn is relational to other strings (Randall 2005). As a theory of quantum physics, the vibration of a string is said to produce a graviton resulting in gravitational force. String theory is therefore an underpinning theory that incorporates all fundamental interactions of the universe. Ferrando suggests posthumanism is consistent with string theory because it aligns with the deconstructed/reconstructed post-dualistic approach. This premise of philosophical posthumanism thereby provides the basis for some very interesting future prospects 
such as the multiverse, where the current space-time continuum may be only one materialized dimension of many possible alternatives.

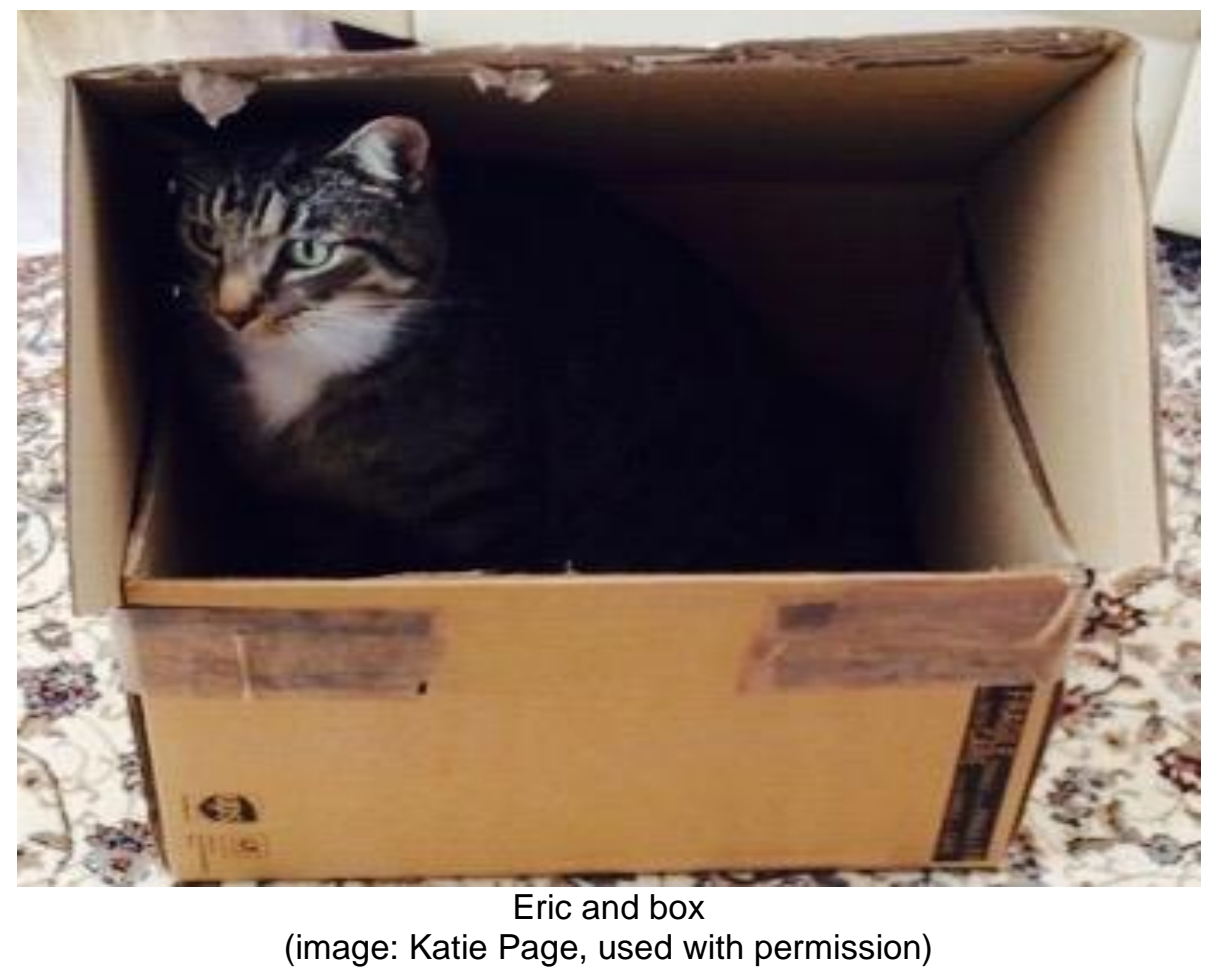

The final part of her thesis is therefore about the possibilities of the multiverse as a philosophical tenet of posthumanism. This is a bold concept to say the least, and draws on different theories including physicist Schrödinger's famous cat thought experiment to explain how quantum mechanics may be applied to pragmatic scenarios. The multiverse theory still highlights dichotomies: here/there, this world/other worlds, this universe/other universes - 'there' being the most distant and unreachable prospect of human imagination which Ferrando argues would benefit from post-humanist, postanthropocentric and post-dualistic reflection. Her treatment of this is not trivial. She examines the concept through a philosophical construction of a posthuman multiverse using a relational perspective by describing a ripple effect of vibrating strings. In such a way, she argues that strings are intra-linked, resulting in or 'revealing' (Heidegger) nodes in a material network. To explain her thoughts further, she uses the metaphor of a rhizome as a possible source of expansion of multiverse theory where any part of the root (think ginger or dahlia or the hyperlinked internet) can spur a new root, resulting in an intra-connected non-hierarchical structure, drawing on Deleuze \& Guattari (1987). Ultimately, Ferrando emphasizes that her argument is 
a position on posthumanist ontological existentialism which, by being both monistic and pluralistic, is post-dualistic.

In conclusion, the text is a foray into a broad range of perspectives that enable the author to critique and position philosophical posthumanism. She situates her work in both humanism and anthropocentrism and destabilises the centricity of the human from other in the process. Whilst ending at a largely untestable philosophical point, the multiverse theory, her means of arguing for a more sustainable or balanced approach as a posthuman is compelling and potentially provides an interesting lens through which researchers could in future deconstruct and explore global and local markets.

\section{Reflections on the Post-Pandemic Worlds}

Where Ferrando's text highlights the issues around resolving the dualism of other in order to improve the relationships between humanity and our environment, COVID-19 has highlighted the imperative for doing so. We may well be posthuman from a range of perspectives, but we are certainly not post-dualistic. The economicallyderived ecosystem through which humanity perceives its environment remains an existential threat in a post-pandemic world (e.g., Dholakia \& Atik 2020).

The pandemic has brought to the fore of our consciousness some of the most profound challenges faced in resolving how we acknowledge human other, especially at the margins of hegemonic techno-scientific endeavors through which vaccines have been developed and deployed, and communities pacified. For example, whereas a local response has been to target older and weaker members of communities, the global response has been based on nationalism, education and access to healthcare systems. Other in this case are those peoples whose lives are shaped by poverty, communal drift and exclusion. Yet without addressing the dualism in humanity surely environmental challenges faced as a consequence of divergent consumption practices can never be balanced.

All species, including humans, are hard-wired to survive and dominate over territories (Darwin 1859; and other evolution theorists), which of necessity pits the self against some other and its environment. At best, this could be described as an harmonious ecosystem, and at worst, a parasitic relationship. The current posthuman challenge is therefore not to resolve the dualism but to find a survivable balance for optimal longevity, recognizing the wider socio-techno-environmental ecosystem in which humans exist with its finite yet evolving others in what Latour and Weibel (2020) refer to as the critical zone of material Earth - that thin habitable region between the Earth's outer crust and space which does not exist elsewhere in the known cosmos. Afterall, neither humans nor others have anywhere else to go. 
Alas, to calculate such planetary balance is beyond even our most advanced computational and scientific capabilities at present which further serves to highlight the precarity of humanity and the strength or survivability of Gaia, depending on whether one's perspective is as an active or passive interrelationship. Either way, what is optimal in such a context? Who knows, but more importantly why should humans care? Ultimately, this is a function of basic human need, possibly redefined as perceived quality of co-existence. Such 'need' underpins the ethos of the United Nations' Sustainable Development Goals, but if our post-pandemic world is to achieve relational balance, then the United Nations must include all nations and representation of all peoples with the best science we can bring to bear on each and every issue. Today's posthuman, reflecting in Ferrando's terms, is frankly still clearly centering the human over non-human others. This is as much about equality in consumption as it is about environmental sustainability. It was only in 2009, for example, that a few predominantly European countries recognized the sentience of animals in its policies, albeit this primarily relates to their treatment in the food chain and only then in the event that policies exist within countries to protect them as 'not things' (e.g., Hudson 2019). This goes no further therefore than positioning humans as lip-servants to saviorism.

So, what about markets in the posthuman post-pandemic world? At its heart, a market is an anthropocentric exchange-based microecosystem. This has some merit in achieving a foundation of balance among humans and possibly a limited number of other species (pets) through a process of virtuous [re-]distribution - what is of value to one may well be of little value to another, and so on. It also is the premise of social enterprises and technology enabled platforms which have become sharing-based economies and digitized commons (e.g., Kwet 2020). These emergent rhizomic markets are, however, not viable without policies that underpin the provision of basic needs for human survivability, which in turn implies a means to legitimize a universal value derived from exchange - the wicked problem that emerges of course is always about whose value the exchange is pegged against. Thus, for a socialist environment to prevail, a complete overhaul of existing market concepts and structures is required, yet how this could be realized in our globalized hyper-connected environment (Hong 2020) is far from clear.

What is interesting in the context of connectivity, however, is that it is not just humans that are connected. There are now innumerable animate, inanimate, organic and inorganic entities which are connected through a vast web using cloud, edge and satellite computing technologies to derive insight for those educated in assimilating and reading the language of digitized data and code 
(known as the 'Internet of All Things'). Others with such skills may not be human but machine, or a network of machines, where intelligence is the currency of exchange. It may be that by working relationally with machines, as hypothesized by Lovelock (2019) in his thesis setting out a post-anthropocentric world, the fundamental need to find and support balance and harmony is achievable.

Such 'intelligent' machines would act as translators between humans and others effectively becoming a post-dualistic binding organ. As we have seen with the numerous dark web incursions on markets over the past months and for years by various state-operating organizations, however, when the data-based environment is not regulated with a global value system derived from equality, chaos ensues. Our relationship with 'intelligent' machines has therefore not begun well with power having slipped into the hands of a few selfinterested entities but perhaps it is not too late to address the problems. Certainly, the environment is filled with complementary empathic drive which creates a much-needed groundswell, what Haraway (2017) refers to as sympoiesis. It is 'simply' that the binding techno-organ has not yet learned to bind.

\section{Concluding Observations}

This Dialogue contribution, substantially through a review of Francesca Ferrando's (2019) book entitled Philosophical Posthumanism, has explored the nexus which we find ourselves at as a consequence of the COVID-19 pandemic. Ferrando's thesis helps us to assess the precariousness of our humanity by developing our understanding of ourselves and our relationship with others - other nations, other species, other worlds. Through analysis, it becomes evident that whilst we are posthuman through a multitude of different lenses, our transition is incomplete - the notion of other creates many challenges in our current market-based ecosystem and the dualism in us-other contexts prevails. Whilst it is clear that becoming cyborg through pandemic pressure has further exacerbated the unbalanced nature of our relationship with our environment, technology may yet be the binding organ that helps us reconfigure globalized markets to achieve equality and balance for a sustainable environment.

This will need more speculative research at a metaversal level, combining virtual and physical environments and entities to develop new concepts in order to evaluate potential impacts on socio-technoenvironmental ecosystems. 


\section{References}

Agamben, Giorgio (2002), The Open: Man and Animal. Trans. Attell, K., (2004), Stanford, US: Stanford University Press.

Arundhati, Roy (2020), "The Pandemic is a Portal," Financial Times, (accessed on April 3, 2021), [available at: https://www.ft.com/content/10d8f5e8-74eb-11ea-95fefcd274e920ca]

Barad, Karen (2007), Meeting the Universe Halfway: Quantum Physics and the Entanglement of Matter and Meaning. Durham, NC: Duke University Press.

Braidotti, Rosi (2002), Metamorphoses: Towards a Materialist Theory of Becoming. Cambridge, UK: Polity.

Cambefort, Marine (2020), "How the COVID-19 Pandemic is Challenging Consumption," Markets, Globalization \& Development Review, 5 (1), Article 2. https://doi.org/10.23860/MGDR-2020-05-01-02

Capra, Fritjof (2010), The Tao of Physics: An Exploration of the Parallels between Modern Physics and Eastern Mysticism. $5^{\text {th }}$ edition, Boston, MA: Shambhala.

Channell, David (1991), The Vital Machine: A Study of Technology and Organic Life. New York, US: Oxford University Press.

Darwin, Charles (1859), On the Origin of Species by Means of Natural Selection: or, the Preservation of Favoured Races in the Struggle for Life. London, UK: John Murray.

De Beauvoir, Simone (1949), The Second Sex. Trans. Borde, C., Malovany-Chevallier, S. (2009), London, UK: Jonathan Cape.

Deleuze, Gilles and Felix Guattari (1987), A Thousand Plateaus: Capitalism and Schizophrenia. London, UK: Continuum.

Dholakia, Nikhilesh and Deniz Atik (2020), "Rethink Everything 1: Markets, Globalization, Development," Markets, Globalization \& Development Review, 5 (1), Article 1. https://doi.org/10.23860/MGDR-2020-05-01-01

Ferrando, Francesca (2019), Philosophical Posthumanism. New York, US: Bloomsbury Press. (2012), Humans, Cyborgs, Posthumans. TEDxSiliconAlley, (uploaded on March 6, 2013), [available at: https://www.youtube.com/watch?v=RGjMUw03Bv0]

Foucault, Michel (1988), Technologies of the Self. Amherst, US: University of Massachusetts Press. (1975), Discipline and Punish: The Birth of the Prison. Trans. Sheridan, A. (1970), New York, US: Random House. 
Haraway, Donna (1985), "A Cyborg Manifesto: Science, Technology and Socialist-Feminism in the late Twentieth Century," in Nicholson, L. (ed.) (1989), Feminism/Postmodernism (Thinking Gender), London, UK: Routledge, 59-57.

Haraway, Donna (2017), Staying with the Trouble: Making Kin in the Chthulucene. London, UK: Duke University Press.

Harman, Graham (2015), "Object oriented Ontology". In Hauskeller, M., Philbeck, T.D., et al, 409-10.

Hassan, I. (1977), "Prometheus as Performer: Toward a Posthumanist Culture?" The Georgia Review, 31 (4): 830-50.

Heidegger, Martin (1977), The Question Concerning Technology and Other Essays. New York, US: Torchbooks.

Hong, Soonkwan (2020), "'Coronated Consumption in the Viral Market," Markets, Globalization \& Development Review, 5 (1), Article 3. https://doi.org/10.23860/MGDR-2020-05-01-03

Huang, Ming-Hui and Roland Rust (2018), "Artificial Intelligence in Service," Journal of Service Research, 21 (2), 155-72. https://doi.org/10.1177/1094670517752459

Hudson, Grace (2019), "Animal Sentience within the Law - An International Perspective," The UK Centre for Animal Law, (accessed on June 26, 2020), [available at: https://www.alaw.org.uk/2019/06/animal-sentience-within-the-lawan-international-perspective-by-grace-hudson/]

Irigaray, Luce (1974), Speculum, of the Other Woman. Trans. Gill, CG. (1985), New York, US: Cornell University Press.

Knight, Rob (2016), Rob's Open Source Android, ROSA, exhibited at the Science Museum, 500-Year Quest to Make Machines Human, September 2017.

Kurzweil, Ray (2005), The Singularity is near: When Humans Transcend Biology. New York, US: Penguin.

Kwet, Michael (2020), "Fixing Society Media: Toward a Democratic Digital Commons," Markets, Globalization \& Development Review, 5 (1), Article 2. https://doi.org/10.23860/MGDR-2020-0501-02

Lamarck, Jean-Baptiste Pierre Antoine de Monet, Chevalier de (1809), Philosophie Zoologique, ou Exposition des Considerations Relative a L'Historie Naturelle de Animaux. Paris. Trans. Macmillan, E.H., London.

Langton, Christopher G. (1986), "Studying Artificial Life with Cellular Automata," Physica D, 22 (1-3), 120-49. https://doi.org/10.1016/0167-2789(86)90237-X

Latour, Bruno (2005), Reassembling the Social: An Introduction to Actor-Network Theory. Oxford, UK: Oxford University Press. 
Latour, Bruno (2017), Facing Gaia: Eight Lectures on the New Climatic Regime. Cambridge, UK: Polity.

and Peter Weibel (2020), Critical Zones: The Science and Politics of Landing on Earth. MIT Press.

Linnaeus, Carl (1758), Systema Naturae per Regna Tria Naturae: Secundum Classes, Ordines, Genera, Species, cum Characteribus, Differentiis, Synonymis, Locis - edition decima, Reformata. Holmiae: Laurentius Salvius.

Lovelock, James (2019), Novacene: The Coming Age of Hyperintelligence, Allen Lane, UK.

Maturana, Humberto and Francisco Varela (1972/1980), Autopoiesis and Cognition: The Realization of the Living. Original Spanish Edition (Chile), later English Edition. Dordrecht, Holland: Reidel Publishing.

McLuhan, Marshall (1964), Understanding Media: The Extensions of Man. New York, US: Signet Books.

Moore, Jason W. (2016), Anthropocene or Capitalocene? Nature, History, and the Crisis of Capitalism. Oakland, US: Kairos.

More, Max (2004), The Proactionary Principle, 1, (accessed on June 29, 2020), [available at: http://jetpress.org/v21/more.htm] (2003), The Principles of Extropy, Version 3.11, The Extropy Institute.

Mori, Masahiro (1970), "The Uncanny Valley," Energy, 7 (4), 33-35. - (1974), The Buddha in the Robot: A Robot Engineer's Thoughts on Science and Religion. Trans. (1981), Tokyo, Japan: Kosei Publishing.

Naidoo, Robin and Brendan Fisher (2020), "Reset Sustainable Development Goals for a Pandemic World," Nature, (accessed on July 6, 2020), [available at: https://www.nature.com/articles/d41586-020-01999-x]

Nietzsche, Friedrich (1901), Thus spoke Zarathustra. Trans., 2006, Del Caro, A., Pippin, R. Cambridge, UK: Cambridge University Press.

Parikka, Jussi (2014), The Anthrobscene. Minneapolis, US: University of Minnesota Press.

Pearce, David (1995), "The Hedonistic Imperative," (accessed on June 29, 2020), [available at: http://www.hedonistic-imperative.com]

Randall, Lisa (2005), Warped Passage: Unravelling the Mysteries of the Universe's Hidden Dimensions. New York, US: Harper Collins.

Rupani, Parveen F., M. Nilashi, R. A. Abumalloh, S. Asadi, S. Samad, and S. Wang. (2020), "Coronavirus Pandemic (COVID-19) and Its Natural Environmental Impacts," International Journal of Environmental Science and Technology, 17, 4855-66. https://doi.org/10.1007/s13762-020-02910-x 
Schrödinger, Erwin (1935), "The Present Situation in Quantum Mechanics". Trans. Drimmer, J. (1980), Proceedings, Cambridge Philosophical Society, 124, 323-38.

Shiva, Vandana (1995), "Democratizing Biology: Reinventing Biology from a Feminist, Ecological and Third World Perspective," in Lederman, M., Bartsch, I. (eds.) (2001), The Gender and science Reader, London, UK: Routledge, 447-65,

Stengers, Isabelle (2015), In Catastrophic Times: Resisting the Coming Barbarism. Trans. Goffey, A., London, UK: Open Humanities Press.

Teilhard de Chardin, Pierre (1964), The Future of Man. New York, US: Harper Row.

Turing, Alan M. (1950), "Computing Machinery and Intelligence," Mind, 59 (236), 433-60.

Ulusoy, Emre (2020), "Elysium as a Social Allegory: At the nexus of Dystopia, Cyberpunk, and Plutocracy," Markets, Globalization \& Development Review, 5 (3), Article 5. https://doi.org/10.23860/MGDR-2020-05-03-05

Vekasi, Kristin (2019), "China's Control of Rare Earth Metals", The National Bureau of Asian Research, (accessed on June 13, 2020), [available at: https://www.nbr.org/publication/chinascontrol-of-rare-earth-metals/]

Warwick, Kevin (2012), Artificial Intelligence: The Basics. Oxford, UK: Routledge.

Woese, Carl (1998), "The Universal Ancestor," PNAS, 95 (12): 685459. 